\title{
Pertumbuhan dan perkembangan larva Musca domestica Linnaeus (Diptera: Muscidae) dalam beberapa jenis kotoran ternak
}

\author{
Growth and development of Musca domestica Linnaeus (Diptera: \\ Muscidae) larvae in different livestock manures \\ Ramadhani Eka Putra $^{1 *}$, Abdul Rosyad ${ }^{1}$, Ida Kinasih ${ }^{2}$ \\ ${ }^{1}$ Sekolah Ilmu dan Teknologi Hayati, Institut Teknologi Bandung, Labtek XI, \\ Jalan Ganesa No. 10, Bandung 40132 \\ ${ }^{2}$ Jurusan Biologi, Fakultas Sains dan Teknologi, Universitas Islam Negeri Sunan Gunung \\ Djati Jalan A.H. Nasution No. 105, Bandung 40614
}

(diterima Januari 2013, disetujui Maret 2013)

\begin{abstract}
ABSTRAK
Lalat rumah (Musca domestica) merupakan serangga urban yang dapat berperan sebagai vektor penyakit. Serangga ini umumnya menggunakan limbah organik sebagai sumber makanan bagi larvanya. Area peternakan merupakan salah satu bentuk industri yang menghasilkan limbah organik yang memiliki potensi sebagai media hidup bagi larva lalat rumah. Area peternakan di Indonesia umumnya terletak pada lokasi yang berdekatan dengan perumahan penduduk sehingga diperlukan suatu metoda untuk pengendalian populasi lalat rumah pada daerah peternakan. Penelitian ini bertujuan untuk mengetahui tingkat perkembangan dari larva lalat rumah yang hidup pada berbagai jenis kotoran ternak. Kotoran yang digunakan adalah kotoran ayam, sapi dan kuda, sedangkan untuk kontrol digunakan bekatul yang merupakan pakan standar pemeliharaan larva lalat rumah di laboratorium. Hasil penelitian menunjukkan bahwa larva yang hidup pada kotoran kuda memiliki laju perkembangan paling tinggi (5 hari), akan tetapi memiliki tingkat keberhasilan hidup larva (30\%), berat pupa $(6,8 \pm 0,141 \mathrm{~g})$, dan berat imago betina $(4,9 \pm 0,14 \mathrm{~g})$ terendah di antara materi uji lainnya. Hal ini mengindikasikan kualitas nutrisi yang rendah pada kotoran ini. Hasil penelitian ini perlu dilanjutkan dengan penelitian pada faktor-faktor yang mempengaruhi pertumbuhan populasi secara langsung, seperti tingkat fekunditas lalat betina dan keberhasilan hidup telur. Dengan penambahan data-data baru pada penelitian lanjutan diharapkan metoda pengendalian populasi lalat rumah pada daerah peternakan dapat didesain dengan tepat.
\end{abstract}

Kata kunci: keberhasilan hidup larva, kotoran ternak, lalat rumah, nutrisi larva, waktu perkembangan

\begin{abstract}
House fly (Musca domestica) is an important urban insect that can transmit various infectious diseases. This insect usually utilized organic wastes as nutrition source for their larvae. One of the main sources of organic wastes is livestock manure produced by animal farming located near human dwelling area. Thus, appropriate house fly population control program at animal farm is needed, based on information on the house fly's life history. The research is focused on the development of house fly larvae reared with different livestock manures, such as cow, chicken, and horse. As comparison, rice bran were used as control. Results showed that larvae reared with horse manure has the shortest development time (5 days), with lowest larval survival rate (30\%), pupal weight (6.8 $\pm 0.141 \mathrm{~g})$, and weight of female imago $(4.9 \pm 0.14 \mathrm{~g})$. This finding indicates the lowest nutrition value of horse manure for house flies larvae. Further research is needed to find the effect of manure
\end{abstract}

\footnotetext{
*Penulis korespondensi: Ramadhani Eka Putra. Sekolah Ilmu dan Teknologi Hayati, Institut Teknologi Bandung, Labtek 
to variables that directly influence population growth, such as fecundity of female flies and egg survivorship. These additional information on life history will help the design of appropriate house fly population management program for animal farm.

Key words: larval survivorship, livestock manure, house flies, larvae nutrition, development time

\section{PENDAHULUAN}

Lalat rumah, Musca domestica, merupakan serangga urban yang mengganggu estetika, merusak makanan, dan berperan sebagai vektor penyakit pada manusia dan hewan ternak (Graczyk et al. 2001; Sehgal et al. 2002; Sukontason 2004; Förster et al. 2007; Jolly 2007; Palacios et al. 2009).

Areal peternakan merupakan lingkungan tempat lalat rumah dapat ditemukan dalam jumlah banyak (Koesharto et al. 1986; Arif 2011; Budiarti 2012; Khan et al. 2012). Melimpahnya limbah organik hewan ternak menyediakan tempat bertelur dan menjadi media tumbuh bagi larva lalat rumah terutama pada daerah-daerah dengan suhu dan kelembaban udara tinggi (Learmount et al. 2002). Sebagian besar peternakan di Indonesia terletak di sekitar pemukiman penduduk sehingga memiliki potensi konflik terutama berkaitan dengan masalah sanitasi (Kaufman et al. 2010; Arif 2011; Budiarti 2012).

Walaupun insektisida dapat digunakan sebagai metode paling mudah untuk menurunkan populasi lalat rumah, hal ini sangat tidak disarankan karena berkaitan dengan masalah toleransi insektisida (Scott et al. 2000) dan efek merugikan pada manusia, hewan ternak, dan organisme non target (Siriwattanarungsee et al. 2008). Oleh karena itu, diperlukan suatu strategi untuk mengendalikan populasi $M$. domestica pada area pertanian tanpa membahayakan lingkungan.

Hal penting dalam merancang program pengendalian serangga hama adalah mengetahui daur hidup dan perilaku serangga hama. Pada penelitian ini, fokus dari pengamatan adalah efek kotoran hewan terhadap daur hidup dari $M$. domestica. Hal ini berkaitan karena nutrisi dapat merubah sejarah hidup dan perilaku (Foster \& Harris 1997) bahkan keberhasilan hidup serangga (Awmack \& Leather 2002). Variabel yang diamati adalah parameter keberhasilan hidup, seperti waktu perkembangan, berat pupa, dan tingkat keberhasilan hidup hingga dewasa (Saeed et al. 2010). Penelitian ini bertujuan untuk mengetahui tingkat perkembangan dari larva lalat rumah yang hidup pada berbagai jenis kotoran ternak. Di harapkan dapat menjadi pertimbangan dalam merancang suatu program manajemen pada peternakan untuk mengurangi populasi $M$. domestica di sekitar daerah peternakan.

\section{BAHAN DAN METODE}

\section{Koleksi telur M. domestica}

Telur M. domestica dikoleksi menggunakan perangkap telur berupa kotoran ternak yang ditempatkan pada gelas plastik berukuran $50 \mathrm{ml}$. Perangkap disimpan di dalam kurungan pemeliharaan $M$. domestica yang berasal dari Bandung koleksi Laboratorium Entomologi, Sekolah Ilmu dan Teknologi Hayati, Institut Teknologi Bandung (SITH ITB) selama \pm 12 jam. Telur lalat yang terkumpul selanjutnya dipindahkan pada wadah terpisah untuk ditentukan jumlahnya menggunakan persamaan alometrik $0,1 \mathrm{~g} \approx 1000$ telur (Pastor et al. 2011).

\section{Persiapan bahan penelitian}

Kotoran ternak yang digunakan pada penelitian ini adalah kotoran ayam, sapi, dan kuda. Kotoran ternak diperoleh dari peternakan sekitar kota Lembang dan Bandung. Kotoran yang baru diekskresikan dimasukkan ke dalam kantong plastik hitam kemudian disimpan dalam lemari pendingin bersuhu $4{ }^{\circ} \mathrm{C}$ sebelum digunakan. Sebagai kontrol digunakan bekatul. Sebelum digunakan, bekatul dihaluskan, kemudian dicampur dengan air dengan perbandingan (bekatul (kg) : air (liter)) $1: 1,5$ (Arief et al. 2012). Setelah dicampur air, bekatul dicampur dengan ragi untuk menghasilkan media hidup larva lalat rumah (Keiding \& Arevad 1964). Bekatul merupakan media yang digunakan pada pemeliharaan larva lalat rumah di Laboratorium Entomologi, SITH ITB. 
Kandungan karbon dan total nitrogen kotoran ternak, sebagai media hidup larva, yang digunakan dianalisis pada Laboratorium Uji Balai Penelitian Tanaman Sayuran, Lembang, Jawa Barat. Analisis kandungan air dilakukan dengan memanaskan sebanyak $70 \mathrm{~g}$ media hidup di dalam oven bersuhu $60^{\circ} \mathrm{C}$ selama 3 hari (Peter et al. 2003).

\section{Pelaksanaan percobaan}

Sebanyak $\pm 0,05$ g telur $M$. domestica $(\approx 500$ butir telur) dimasukkan ke dalam gelas plastik berukuran $500 \mathrm{ml}$ yang telah berisi $70 \mathrm{~g}$ kotoran ternak. Gelas-gelas tersebut kemudian diletakkan dalam ruangan bersuhu $25{ }^{\circ} \mathrm{C}$ dengan periode terang : gelap $12: 12$. Untuk mengukur suhu dalam setiap media hidup, sebuah termometer dimasukkan hingga $\pm 2 / 3$ kedalaman media hidup.

Waktu menetas telur dan hari pertama kali pupa dikoleksi, dicatat. Berat dan panjang ratarata 30 individu larva dari tiap gelas uji diambil dan dicatat setiap hari. Berat prapupa diukur dan dicatat sebagai berat akhir larva. Pupa yang ditemukan, ditimbang dan diukur berat serta panjangnya kemudian dipindahkan ke dalam gelas plastik berukuran $500 \mathrm{ml}$ untuk kemudian diamati lama kemunculan imago. Imago yang muncul dicatat jenis kelaminnya dan diukur berat dan panjang tubuhnya. Penelitian dilakukan pada bulan Januari hingga Oktober 2011.

\section{Analisis data}

Perbedaan rata-rata berat dan panjang tubuh prapupa, pupa dan imago dianalisis menggunakan ANOVA dan analisis lanjutan Tukey pada taraf $\alpha=5 \%$ melalui perangkat lunak SPSS 13 (SPSS Inc. 2005). Keberhasilan hidup larva ditentukan berdasarkan proporsi larva yang mencapai tahap pupasi dari total populasi larva. Formula Abbott dipergunakan untuk menentukan nilai koreksi besar mortalitas larva akibat kematian oleh sebab alami yang mungkin terjadi selama percobaan berlangsung (Abbott 1925).

$$
\% \text { koreksi }=1-\frac{\begin{array}{c}
\text { Jumlah serangga dalam kelom- } \\
\text { pok uji setelah perlakuan }
\end{array}}{\begin{array}{c}
\text { Jumlah serangga dalam kontrol } \\
\text { setelah perlakuan }
\end{array}} \times 100
$$

\section{HASIL}

\section{Suhu, kandungan air dan organik media hidup larva M. domestica}

Analisis kotoran hewan menunjukkan seluruh media hidup yang digunakan memiliki faktor fisik yang menunjang kehidupan larva $M$. domestica, yaitu bersuhu $16{ }^{\circ} \mathrm{C}$ hingga $35{ }^{\circ} \mathrm{C}$ dengan kadar air berkisar dari $60 \%$ hingga $80 \%$ (Stafford et al. 2008). Analisis kandungan organik menunjukkan bahwa kandungan karbon tertinggi terdapat pada bekatul sebagai kontrol dan kotoran ayam sebagai bahan uji, sedangkan kandungan nitrogen tertinggi dimiliki oleh kotoran ayam (Tabel 1 ). $\mathrm{C} / \mathrm{N}$ rasio tertinggi dimiliki oleh bekatul (sebesar 33,03) diikuti oleh kotoran kuda $(23,26)$, kotoran sapi $(16,68)$, dan kotoran ayam $(9,55)$.

\section{Lama perkembangan larva dan persentase keberhasilan hidup larva}

Berdasarkan data yang diperoleh diketahui bahwa perkembangan larva tercepat ditemukan pada kotoran kuda, yaitu 5 hari, sedangkan perkembangan terlambat ditemukan pada larva yang hidup pada kotoran sapi, yaitu 10 hari (Tabel 2). Sementara itu, tingkat keberhasilan hidup larva $M$. domestica yang terendah adalah pada larva yang dipelihara pada kotoran kuda (30\%), diikuti pada kotoran sapi (61\%), serta kotoran ayam dan bekatul sebagai kontrol (90\%) (Tabel 2).

\section{Berat dan panjang tubuh prepupa dan pupa}

Hasil analisis menunjukkan bahwa rata-rata berat larva instar akhir berbeda secara signifikan diantara perlakukan $\left(\mathrm{F}_{3,399}=155,166 ; \mathrm{P}=0,000\right)$, sedangkan rata-rata panjang larva beragam di antara perlakukan $\left(\mathrm{F}_{3,399}=12,629 ; \mathrm{P}=0,000\right)$. Larva terberat dan terpanjang ditemukan pada bekatul dan yang teringan dan terpendek ditemukan pada kotoran kuda (Tabel 3).

Hasil analisis menunjukkan bahwa rata-rata berat pupa berbeda signifikan diantara perlakukan $\left(\mathrm{F}_{3,399}=91,831 ; \mathrm{P}=0,000\right)$, sedangkan ratarata panjang pupa beragam diantara perlakukan $\left(\mathrm{F}_{3,399}=21,285 ; \mathrm{P}=0,000\right)$. Melalui data tabel 3, dapat diketahui bahwa pupa terberat diperoleh dalam bekatul $(0,014 \mathrm{~g})$ sedangkan yang teringan diperoleh dalam kotoran kuda $(0,0068 \mathrm{~g})$. 
Melalui data ini pula dapat diketahui bahwa pupa terpanjang ditemukan pada kotoran ayam $(5 \mathrm{~cm})$, sedangkan yang terpendek ditemukan dalam kotoran kuda $(4,4 \mathrm{~cm})$.

\section{Berat dan panjang tubuh imago}

Hasil analisis menunjukkan bahwa rata-rata berat imago jantan berbeda signifikan diantara perlakukan $\left(\mathrm{F}_{3,399}=44,51 ; \mathrm{P}=0,000\right)$, sedangkan rata-rata panjang imago jantan beragam diantara perlakukan $\left(\mathrm{F}_{3,399}=19,656 ; \mathrm{P}=0,000\right)$. Hasil analisis serupa juga terlihat pada berat rata-rata imago betina yang beda rata-rata secara signifkan terlihat diantara perlakukan $\left(\mathrm{F}_{3,399}=41,37 ; \mathrm{P}=\right.$ $0,000)$, sedangkan panjang rata-rata imago betina beragam diantara perlakukan $\left(\mathrm{F}_{3,399}=24,146\right.$; $\mathrm{P}=0,000)$. Berdasarkan hasil analisis ini dapat diketahui bahwa rata-rata berat dan panjang tubuh imago terbesar ditemukan pada bekatul, sedangkan yang terkecil ditemukan pada kotoran kuda (Tabel 4).

\section{PEMBAHASAN}

Penelitian ini menunjukkan bahwa perkembangan larva sangat bervariasi pada berbagai

Tabel 1. Kondisi fisika dan kimia media hidup larva Musca domesica

\begin{tabular}{lcccc}
\hline \multirow{2}{*}{ Jenis media hidup } & Kadar air $(\%)$ & Rata-rata suhu harian $\left({ }^{\circ} \mathrm{C}\right)$ & \multicolumn{2}{c}{ Kandungan organik } \\
\cline { 3 - 5 } & $64 \pm 0,8$ & 26 & Karbon & Total Nitrogen \\
\hline Bekatul & $70 \pm 0,5$ & 25 & 17,96 & 0,76 \\
Kotoran Ayam & $79 \pm 0,2$ & 25 & 14,68 & 0,88 \\
Kotoran Sapi & $68 \pm 0,3$ & 25 & 12,33 & 0,53 \\
Kotoran Kuda & & & 258 \\
\hline
\end{tabular}

Tabel 2. Lama perkembangan dan kelulushidupan larva Musca domestica pada berbagai media hidup

\begin{tabular}{lcc}
\hline Jenis media hidup & $\begin{array}{c}\text { Lama perkembangan } \\
\text { larva (hari)* }\end{array}$ & $\begin{array}{c}\text { Keberhasilan } \\
\text { hidup (\%) }\end{array}$ \\
\hline Bekatul & $7 \pm 0,7 \mathrm{a}$ & 90 \\
Kotoran Ayam & $7 \pm 0,8 \mathrm{~b}$ & 90 \\
Kotoran Sapi & $10 \pm 0,5 \mathrm{c}$ & 61 \\
Kotoran Kuda & $5 \pm 0,7 \mathrm{~d}$ & 30 \\
\hline
\end{tabular}

* Total larva yang digunakan adalah 400 individu, huruf yang berbeda menunjukkan perbedaan signifikan secara statistik $(\alpha=5 \%)$.

Tabel 3. Rata-rata berat prepupa dan pupa Musca domestica yang hidup pada media berbeda

\begin{tabular}{|c|c|c|c|c|}
\hline \multirow{2}{*}{ Jenis media hidup } & \multicolumn{2}{|c|}{ Larva* } & \multicolumn{2}{|c|}{ Pupa* } \\
\hline & Berat (mg) & Panjang (mg) & Berat (mg) & Panjang (mg) \\
\hline Bekatul & $16,4 \pm 0,44 \mathrm{a}$ & $8,9 \pm 0,14$ eg & $14,0 \pm 0,48 \mathrm{i}$ & $4,6 \pm 0,08 \mathrm{mo}$ \\
\hline Kotoran Ayam & $14,3 \pm 0,36 \mathrm{~b}$ & $9,1 \pm 0,08 \mathrm{e}$ & $11,6 \pm 0,36 \mathrm{j}$ & $5,05 \pm 0,05 \mathrm{n}$ \\
\hline Kotoran Sapi & $10,7 \pm 0,23 \mathrm{c}$ & $8,5 \pm 0,10 \mathrm{gh}$ & $8,9 \pm 0,22 \mathrm{k}$ & $4,64 \pm 0,05$ o \\
\hline Kotoran Kuda & $7,5 \pm 0,15 \mathrm{~d}$ & $8,2 \pm 0,83 \mathrm{~h}$ & $6,8 \pm 0,141$ & $4,4 \pm 0,05 \mathrm{~m}$ \\
\hline
\end{tabular}

* Total larva yang digunakan adalah 400 individu, huruf yang berbeda menunjukkan perbedaan signifikan secara statistik $(\alpha=5 \%)$.

Tabel 4. Rata-rata berat dan panjang imago M. domestica

\begin{tabular}{|c|c|c|c|c|}
\hline \multirow{2}{*}{ Jenis media hidup } & \multicolumn{2}{|c|}{ Jantan* } & \multicolumn{2}{|c|}{ Betina* } \\
\hline & Berat $(\mathrm{mg})^{*}$ & Panjang (mg) & Berat (mg) & Panjang (mg) \\
\hline Bekatul & $8,2 \pm 0,16 \mathrm{a}$ & $5,1 \pm 0,07 \mathrm{e}$ & $8,7 \pm 0,17 \mathrm{~h}$ & $5,2 \pm 0,051$ \\
\hline Kotoran Ayam & $7,3 \pm 0,28 b$ & $5 \pm 0,10 \mathrm{e}$ & $7,2 \pm 0,35 \mathrm{i}$ & $5,1 \pm 0,091$ \\
\hline Kotoran Sapi & $5,9 \pm 0,13 \mathrm{c}$ & $4,6 \pm 0,05 \mathrm{~g}$ & $6,1 \pm 0,11 \mathrm{j}$ & $4,74 \pm 0,05 \mathrm{n}$ \\
\hline Kotoran Kuda & $4,9 \pm 0,12 \mathrm{~d}$ & $4,35 \pm 0,06 \mathrm{~g}$ & $4,9 \pm 0,14 \mathrm{k}$ & $4,4 \pm 0,07 \mathrm{o}$ \\
\hline
\end{tabular}

* Total larva yang digunakan adalah 400 individu, huruf yang berbeda menunjukkan perbedaan signifikan secara statistik $(\alpha=5 \%)$. 
tipe kotoran ternak (Patricia \& Claudio 2008; Khan et al. 2012) bergantung pada faktor nutrisi dan phagostimulant (Myers et al. 2008). Hasil penelitian ini menunjukkan bahwa larva yang hidup pada kotoran kuda memiliki durasi perkembangan larva paling singkat, yaitu selama 5 hari. Menurut Stafford et al. (2008), pada kondisi lingkungan bersuhu \pm 25 ; berkelembaban $\pm 70 \%$, lama perkembangan larva $M$. domestica adalah 7 hingga 10 hari. Perkembangan larva $M$. domestica yang singkat pada kotoran kuda yang ditemukan pada penelitian ini memiliki perbedaan dengan hasil yang diperoleh oleh Patricia \& Claudio (2008) serta Khan et al. (2012). Waktu perkembangan yang singkat ini diikuti dengan tingkat mortalitas larva yang tinggi, terutama pada awal masa larva (pengamatan pribadi) serta ukuran pupa yang lebih kecil dibandingkan dengan larva yang dipelihara pada kotoran ternak lainnya. Hasil yang diperoleh ini kemungkinan disebabkan oleh mekanisme bertahan hidup pada larva dengan cara mempercepat metabolisme tubuhnya dan mempersingkat waktu perkembangan larvanya pada kondisi kekurangan nutrisi atau perubahan pada lokasi hidupnya (Slansky \& Rodriquez 2004). Konsekuensi dari mekanisme ini adalah siklus hidup yang pendek dan pertumbuhan populasi yang singkat (Singh \& Parihar 1988) sehingga memungkinkan terjadinya ledakan populasi bila kondisi nutrisi dan lingkungan berubah menjadi lebih baik. Sayangnya, penelitian ini tidak mengamati tingkat fekunditas dari lalat dewasa sebagai salah satu syarat, selain waktu perkembangan yang cepat dan kesesuaian suatu substrat sebagai media hidup larva (Awmack \& Leather 2002).

Kotoran sapi dapat dikatakan sebagai media yang kurang sesuai sebagai media hidup larva M. domestica yang ditunjukkan oleh laju perkembangan yang lambat dan tingkat mortalitas larva yang tinggi. Hal ini kemungkinan disebabkan oleh nilai $\mathrm{C} / \mathrm{N}$ rasio tinggi sebagai konsekuensi dari makanan yang kaya akan serat tumbuhan (Bary et al. 2004). Nilai C/N rasio yang tinggi akan menghambat proses pertumbuhan mikroba yang merupakan komponen penting pada nutrisi bagi larva lalat rumah.

Sementara itu, larva yang dipelihara pada bekatul dan kotoran ayam memiliki keberhasilan hidup yang tinggi dengan dua alasan yang berbeda. Kotoran ayam umumnya memiliki nilai $\mathrm{C} / \mathrm{N}$ yang rendah (Moon et al. 2001) karena pakan ayam mengandung protein tinggi. Rasio $\mathrm{C} / \mathrm{N}$ yang tinggi akan meningkatkan aktivitas mikroba yang penting bagi perkembangan larva $M$. domestica. Pada bekatul, proses fermentasi yang terjadi setelah penambahan ragi meningkatkan kandungan gula dan protein pada substrat yang memberikan nutrisi secara langsung maupun tidak langsung dengan meningkatkan jumlah mikroba penting bagi proses perkembangan larva.

Hal lain yang ditunjukkan pada hasil penelitian ini adalah kadar air media yang sebelumnya diduga sebagai faktor penting dalam proses perkembangan larva M. domestica (Chen 1946; Hogsette 1996), ternyata tidak berpengaruh terhadap kecepatan perkembangan maupun keberhasilan hidup larva sehingga dapat disimpulkan bahwa efek kadar air media tidak sebesar nutrisi dalam mempengaruhi perkembangan larva lalat rumah.

Larva yang hidup pada bekatul memiliki berat dan panjang tubuh terbesar sementara larva yang hidup pada kotoran kuda memiliki berat dan panjang tubuh terkecil. Hasil ini menunjukkan bahwa kotoran kuda merupakan media yang tidak cocok untuk pertumbuhan lalat rumah yang dapat disebabkan oleh beberapa hal. (1) Rendahnya kandungan nitrogen pada kotoran kuda sehingga menurunkan aktivitas mikroba. Larva lalat dari kelompok muscoid memiliki kecenderungan untuk mengkonsumsi mikroorganisme dibandingkan dengan material terdekomposisi pada substrat (Ferrar 1987). (2) Kemungkinan tingginya kandungan tanin pada kotoran kuda. Tanin telah diketahui mampu menghambat proses perkembangan larva lalat rumah yang hidup pada kotoran ternak (Littlefield et al. 2011). Tanin pada kotoran kuda berasal dari daun atau kulit kayu yang diberikan sebagai pakan. Kemungkinan ini perlu dibuktikan kembali dengan penelitian lebih lanjut karena pada penelitian ini hal tersebut tidak dilakukan.

Secara umum, berat badan yang dimiliki larva dan prapupa menggambarkan jumlah nitrogen yang berhasil diserap oleh tubuh larva dan banyaknya energi yang disimpan untuk digunakan pada proses pembentukan organ dan jaringan imago dalam metamorfosis (Horie \& Watanabe 
1983; Pastor et al. 2011). Data yang diperoleh pada penelitian ini menunjukkan bahwa pupa dari larva yang dipelihara dalam kotoran kuda memiliki berat dan ukuran pupa terendah. Hal ini kemungkinan merupakan efek dari penyesuaian yang dilakukan oleh larva pada kotoran kuda dengan mempercepat proses perkembangan.Berat pupa yang rendah dapat memberikan konsekuensi besar pada pertumbuhan populasi sebab fekunditas serangga betina sangat dipengaruhi oleh ukuran pupa (Black \& Krafsur 1987).

Rendahnya nilai berat dan panjang tubuh imago yang hidup dalam kotoran kuda merupakan bentuk konsekuensi yang diterima larva $M$. domestica karena mempercepat lama perkembangannya (Slansky \& Rodriquez 2004). Penelitian ini sendiri tidak menemukan perubahan rasio ukuran tubuh imago betina dan jantan akibat perbedaan media hidup pada larva, seperti hasil penelitian Arroyo (2011) yang menunjukkan bahwa imago betina memiliki ukuran tubuh yang lebih panjang daripada imago jantan.

\section{KESIMPULAN}

Penelitian ini menunjukkan terdapat perbedaan pada tingkat perkembangan dan pertumbuhan dari larva lalat rumah yang hidup pada kotoran ternak yang berbeda. Berdasarkan pada rata-rata waktu perkembangan, keberhasilan hidup larva, dan ukuran tubuh imago maka urutan dari kotoran hewan yang terbaik sebagai media hidup larva lalat rumah adalah kotoran ayam, kotoran kuda, dan kotoran sapi. Penelitian ini perlu dilanjutkan untuk mendapatkan data pada fekunditas imago betina, dan tingkat keberhasilan hidup telur dari generasi yang hidup pada kotoran ternak tertentu sehingga dapat diduga tingkat pertumbuhan dari populasi lalat rumah dan menjelaskan apakah perubahan pada mekanisme perkembangan berkompensasi terhadap perkembangan populasi mereka di alam terutama pada kotoran kuda.

\section{UCAPAN TERIMA KASIH}

Penelitian ini dibiayai oleh progam INSINAS dari Kemenristek yang diterima oleh REP.

\section{DAFTAR PUSTAKA}

Abbott WS. 1925. A method of computing the effectiveness of an insecticide. Journal of Economic Entomology 18:265-267.

Arif S. 2011. Meresahkan, Peternakan Ayam 4 Hektar Digugat Warga. Harian Okezone edisi Jumat, 11 November 2011. Blitar, Jawa Timur.

Arief M, Ratika AN, Lamid M. 2012. Pengaruh kombinasi media bungkil kelapa sawit dan dedak padi yang difermentasi terhadap produksi maggot Hermetia illucens sebagai sumber protein pakan ikan. Jurnal Ilmiah Perikanan dan Kelautan 4:15.

Arroyo SH. 2011. House fly, Musca domestica Linneaus. Florida: Bulletin of University of Florida.

Awmack CS, Leather SR. 2002. Host plant quality and fecundity inherbivorous insects. Annual Review of Entomology 47:817-844. http://dx.doi. org/10.1146/annurev.ento.47.091201.145300.

Bary A, Cogger C, Sullivan DM. 2004. Fertilizing with Manure. Washington: Apacific Northwest Extension Publication, Washington State University.

Black K, Krafsur E. 1987. Fecundity and size in the house fly: investigations of some environmental sources and genetic correlates of variation. Medical and Veterinary Entomology 1:369-382. http://dx.doi.org/10.1111/j.1365-2915.1987. tb00368.x.

Budiarti E. 2012. Ternak Ayam di Desa Pandasari Bau dan Meresahkan Warga. Harian Tribun edisi Rabu, 25 Januari 2012. Lampung, Sumatra.

Chen SH. 1946. Evolution of the insect larva. Transactions of the Royal Entomological Society of London 97:381-404. http://dx.doi. org/10.1111/j.1365-2311.1946.tb00270.x.

Ferrar P. 1987. A Guide to the Breeding Habits and Immature Stages of Diptera Cyclorrhapha. Copenhagen: E.J. Brill/Scandinavian Science Press.

Förster M, Klimpel S, Mehlhorn H, Sievert K, Messler S, Pfeffer K. 2007. Pilot studies on synantropic flies (e.g. Musca, Sarcophaga, Calliphora, Fania, Lucilia, Stomoxys) as vectors of pathogenic microorganisms. Parasitology Research 101:243-246. http://dx.doi.org/10.1007/ s00436-007-0522-y.

Foster SP, Harris MO. 1997. Behavioural manipulation methodsfor insect pest management. 
Annual Review of Entomology 42:123-146. http:// dx.doi.org/10.1146/annurev.ento.42.1.123.

Graczyk TK, Knight R, Gilman RH, Cranfield MR. 2001. The role of non-biting flies in the epidemiology of human infectious diseases. Microbes and Infection 3:231-235. http://dx.doi. org/10.1016/S1286-4579(01)01371-5.

Hogsette J. 1996. Development of house flies (Diptera: Muscidae) insand containing varying amounts of manure solids and moisture. Journal of Economic Entomology 89:940-945.

Horie Y, Watanabe K. 1983. Effect of varios kinds of dietary protein and supplementation with limiting amino acids on growth, hemolymph components and uric acid exretion in the silk worm. Journal of Insect Physiology 29:187-99. http://dx.doi. org/10.1016/0022-1910(83)90143-9.

Jolly A. 2007. Houseflies can spreed bird flu virus: Study. Available at: http:// www. thepoultrysite. com/poultrynews/12296/houseflies-can-spreadbird-flu-virus-study. [accessed 10 Agustus 2010].

Kaufman PE, Nunez S, Mann RS, Geden CJ, Scharf ME. 2010. Nicotinoid and pyrethroid insecticide resistance in houseflies (Diptera: Muscidae) collected from Florida dairies. Pest Management Science 66:290-294. http://dx.doi.org/10.1002/ ps. 1872 .

Keiding J, Arevad K. 1964. Procedure and equipment for rearing a large number of housefly strains. Bulletin of the World Health Organization 31:527-528.

Khan HAA, Shad SA, Akram W. 2012. Effect of livestock manures on the fitness of house fly, Musca domestica L. (Diptera: Muscidae). Parasitology Research 111:1165-1171. http:// dx.doi.org/10.1007/s00436-012-2947-1.

Koesharto FX, Sigit SH, Kesumawati U. 1986. Suatu Telaah Penggunaan Musuh Hayati (serangga parasit dan predator) untuk Pemberantasan lalat pengganggu (Diptera: Muscidae) pada ternak Sapi dan Kerbau. Laporan Penelitian. Bogor: Fakultas Kedokteran Hewan, Institut Pertanian Bogor.

Learmount J, Chapman P, Macnicoll A. 2002. Impact of an insecticide resistance strategy for house fly (Diptera: Muscidae) control in intensive animal units in the United Kingdom. Journal of Economic Entomology 95:1245-1250. http:// dx.doi.org/10.1603/0022-0493-95.6.1245.

Littlefield KA, Muir JP, Lambert BD, Tomberlin JK. 2011. Condensed tannins inhibit house fly (Diptera: Muscidae) development in livestock manure. Environmental Entomology 40:15721576. http://dx.doi.org/10.1603/EN11091.

Moon R, Hinton J, O'Rourke S, Schmidt D. 2001. Nutritional value offresh and composted poultry manure for house fly (Diptera: Muscidae) larvae. Journal of Economic Entomology 94:1308-1317. http://dx.doi.org/10.1603/0022-0493-94.5.1308.

Myers HM, Tomberlin JK, Lambert BD, Kattes D. 2008. Development of black soldier fly (Diptera: Stratiomyidae) larvae fed dairy manure. Environmental Entomology 37(1):11-5. http:// dx.doi.org/10.1603/0046-225X(2008)37[11:DO BSFD]2.0.CO;2.

Palacios SM, Bertoni A, Rossi Y, Santander R, Urzua A. 2009. Insecticidal properties of essential oils from native medicinalplants of Central Argentina against the house fly, Musca domestica (L.). Parasitology Research 106:207-212. http:// dx.doi.org/10.1007/s00436-009-1651-2.

Pastor B, Cickova H, Kozanek M, Martinez-Sanchez A, Takac P, Rojo S. 2011. Effect of the size of the pupae, adult diet, oviposition substrate and adult population density on egg production in Musca domestica (Diptera: Muscidae). European Journal of Entomology 108:587-596.

Patricia LS, Clandio SF. 2008. House fly (Diptera: Muscidae) development in different types of manure. Journal of Agricultural Research of Chile 68:192-197.

Peter J, Combs S, Hoskins B, Jarman J, Kovar J, Watson M, Wolf A, Wolf N. 2003. Recommended Methods of Manure Analysis. Wisconsin: University of Wisconsin.

Saeed R, Sayyed AH, Shad SA, Zaka SM. 2010. Effect of different host plants on the fitness of diamondback moth, Plutella xylostella (Lepidoptera: Plutellidae). Crop Protection 29:178-182. http:// dx.doi.org/10.1016/j.cropro.2009.09.012.

Scott JG, Alefantis TG, Kaufman PE, Rutz DA. 2000. Insecticide resistance in house flies from caged layer poultry facilities. Pest Management Science 56:1-7. http://dx.doi. org/10.1002/1526-4998(200002)56:2<147::AIDPS106>3.0.CO;2-7.

Sehgal R, Bhatti HP, Bhasin DK, Sood AK, Nada R, Malla N, Singh K. 2002. Intestinal myiasis due to Musca domestica: a report of twocases. Japanese Journal of Infectious Diseases 55:191-193.

Singh OP, Parihar SBB. 1988. Effect of different hosts on the development of Heliothis armigera. Bulletin of Entomological Research 29:21682172. 
Siriwattanarungsee S, Sukontason KL, Olson JK, Chailapakul O, Sukontason K. 2008. Efficacy of neem extract against the blowflyand housefly. Parasitology Research 103:535-544. http:// dx.doi.org/10.1007/s00436-008-1004-6.

Slansky FJr, Rodriguez JG. 2004. Nutritional Ecology of Insects, Mites, Spiders, and Related Invertebrates. US: Wiley.

SPSS Inc. Released 2005. SPSS for Windows, Version 13.0. Chicago, SPSS Inc.

Stafford, KC III, Collison CH. 2008. Fly Management Handbook: A Guide to Biology, Dispersal, and Management of The House Fly and Related
Flies for Farmers, Municipalities and Public Health Officials. New Haven: The Connecticut Agricultural Experiment Station US.

Sukontason KL, Boonchu N, Sukontason K, Choochote W. 2004. Effects of eucalyptol on house by (Diptera:Muscidae) and blow by (Diptera: Calliphoridae). Revista do Instituto de Medicina Tropical de São Paulo 46:97-101. http:// dx.doi.org/10.1590/S0036-46652004000200008. 